\title{
Game Design Factor Questioner in User Experience Analysis on Selera Nusantara Game
}

\author{
K Widhiyanti" ${ }^{* 1}$, K Dewangga ${ }^{2}$, F Almukhtar ${ }^{3}$ \\ ${ }^{1}$ Department of Animation, Institut Seni Indonesia Yogyakarta. \\ ${ }^{2}$ Department of Information Technology, Lembaga Pendidikan Perkebunan Agro \\ Nusantara. \\ ${ }^{3}$ Department of Information Technology, Catholic University in Erbil, Kurdistan \\ Region, Iraq.
}

E-mail: kathryn@isi.ca.id ${ }^{1}$, kdewangga85@gmail.com², f.almukhtar@cue.edu.krd³

Submitted: 16 Jan 2022, revised: 16 Feb 2022, accepted: 23 Feb 2022

\begin{abstract}
Game products are one of the media to provide pleasure, satisfaction, and also knowledge for its users. Selera Nusantara Game is one of the game products by the game studio in Yogyakarta, Gambir Studio, created with the aim to provide pleasure, satisfaction, and knowledge to its users. In order for Selera Nusantara Game to be achieved, a game design is needed by a user-centered game designer. Selera Nusantara game is a game with a casual genre that has a target audience of non-gamer women with the main goal is to introduce Nusantara cuisine that is often encountered by the general public. The good purpose of the Selera Nusantara Game which introduces Nusantara culture became the basis of this research by assessing the quality of the game in order to be optimally accepted by the target audience. The User Experience method with Game Design Factor Questionnaire and compared to the results of an interview with game designers from Selera Nusantara Game used in this study provides a quantitative analysis of the quality of the game. The results of the analysis showed that Selera Nusantara Game has a high score of $>75 \%$ with a significant difference in the choice of agreeing and strongly agreeing to other options, namely on the factors of Game Goals, Game Mechanism, Interaction, Fantasy Game, Narrative, Sensation, and Game Value. This means that the Selera Nusantara Game can fulfill the goal of providing pleasure, satisfaction, and knowledge to its users by the design of the game designer.
\end{abstract}

Keywords: user experience, GDFQ, game evaluation.

\section{Introduction}

Nowadays, the game has become a part of everyone's life, especially with the Covid-19 pandemic conditions that make almost everyone stay at home. In this condition, humans feel the role of technology in carrying out every activity [1]. Digital games are one of the technologies that are an

Widhiyanti, Dewangga, Almukthar (Game Design Factor Questioner in User Experience Analysis on Selera Nusantara Game) 
option as a medium of entertainment. Game products have the purpose of entertaining and sometimes indirectly providing knowledge for their players. This goal is certainly the basis for Game Designer in designing a game that can provide benefits for its users. In the design of a game, Game Designer will process from several aspects related to the creation of a game such as a story, game flow (gameplay), game algorithm, and of course game evaluation. Game Designer certainly does not forget the user's involvement in the game design process. One of the main elements of the success of the gaming industry is the experienced players feel when playing a game [2]. A good game design will certainly provide satisfaction for its users. The design of interaction between users and game products, especially digital games, is certainly the main point to achieve the goal of the game designer when designing a game. The complicated user interface makes users confused in using applications [2][3]. The interest and attachment of game users will be very influential in the business side of selling games.

It is important to not take all creative control away from the designer because this would clearly diminish the game experience as good game design is anything but random and arbitrary [4]. A Game Developer certainly needs to conduct a product test to find out if the resulting game is by the purpose of the game's distribution. To find out the level of success of the UX implemented in order to meet the needs and satisfaction of users, it is necessary to do an evaluation [5]. There are several methods of game evaluation that can be applied to test a game. One of them is by observing the user experience when playing the game. Testing by looking at the user experience is expected to find out how much satisfaction the game player, towards the game created. User Experience is a method of testing an application to see the interaction between users and the product created.

In this study, an evaluation was conducted on a digital game with the title Selera Nusantara which was produced by a Game Studio in Yogyakarta, Gambir Studio. Selera Nusantara Game is a game with a casual genre, which is a game with characteristics that are easy to play. Selera Nusantara Game has been released through the Play Store and App Store on August 16, 2021, and there have been more than 1,000,000 downloads. The number of downloads and reviews from users through the Play Store and App Store became the basis in the research for the evaluation of Nusantara Taste Games. The evaluation method used in the study was user experience using the Game Design Factor Questionnaire (GDFQ). The GDFQ method used is an evaluation method created specifically for gaming product [6]. User experience is critical to the success of a game in the market, especially in recently released types of apps [7]. The results of this research will be included for Game Developers and can be a reference for the development of Selera Nusantara Game in the future.

\section{Game Design Framework}

\subsection{Game}

A game or game is a recreational activity to fill free time, have fun, or exercising lightly. Each game has different rules and characteristics so there are a wide variety of game genres.

\subsection{User Experience}

User experience is a person's experience when using a product, system, or service. User experience in aspects of experience, level of ease, usability, and efficiency and effectiveness of a system[8]. The feeling of use when running a product can be identified from the user experience obtained when using it[9]. User Experience (UX) is a process in product design that aims to integrate and improve the interaction between products and their users in aspects of design, branding, usability, and function. When designing games Game Developer usually focuses on what kind of games will be made by game designers, but sometimes forgets the needs of their users later. The ability to understand users, one of which is user experience or UX should be owned by a game designer in order to produce a

\footnotetext{
Widhiyanti, Dewangga, Almukthar (Game Design Factor Questioner in User Experience Analysis on Selera Nusantara Game)
} 
game that makes players interested when playing it, feeling satisfied, and finally become loyal or can last a long time to play the game. Evaluation using UX becomes an important thing to be done by a Game Designer in order to understand the needs, limitations, and capabilities of its target users.

\subsection{Game Design Factor Questionnaire}

Game-Design Factors can be used to assist Game Designers in designing a digital game. Game-Design Factors have 11 crucial factors and one additional factor in game design including: Game Goals, Game Mechanism, Interaction, Freedom, Fantasy Game, Narrative, Sensation, Game Value, Challenges, Sociality, Mystery, Flow [2].

\section{Method}

The method applied in this study is accompanied by a literacy study of the methods used for game evaluation as well as the application of Selera Nusantara Game. The next stage is an interview with Game Developer, especially Game Designer. The data from the interviews were processed in a qualitative descriptive way. In addition to interviews, data collection was also conducted by questionnaire method with respondents who had criteria such as targets from the Selera Nusantara Game design. The results of data collection are then processed using quantitative descriptive methods and compared with the results of interview analysis with Game Developers. Figure 1 shows the process of this study.

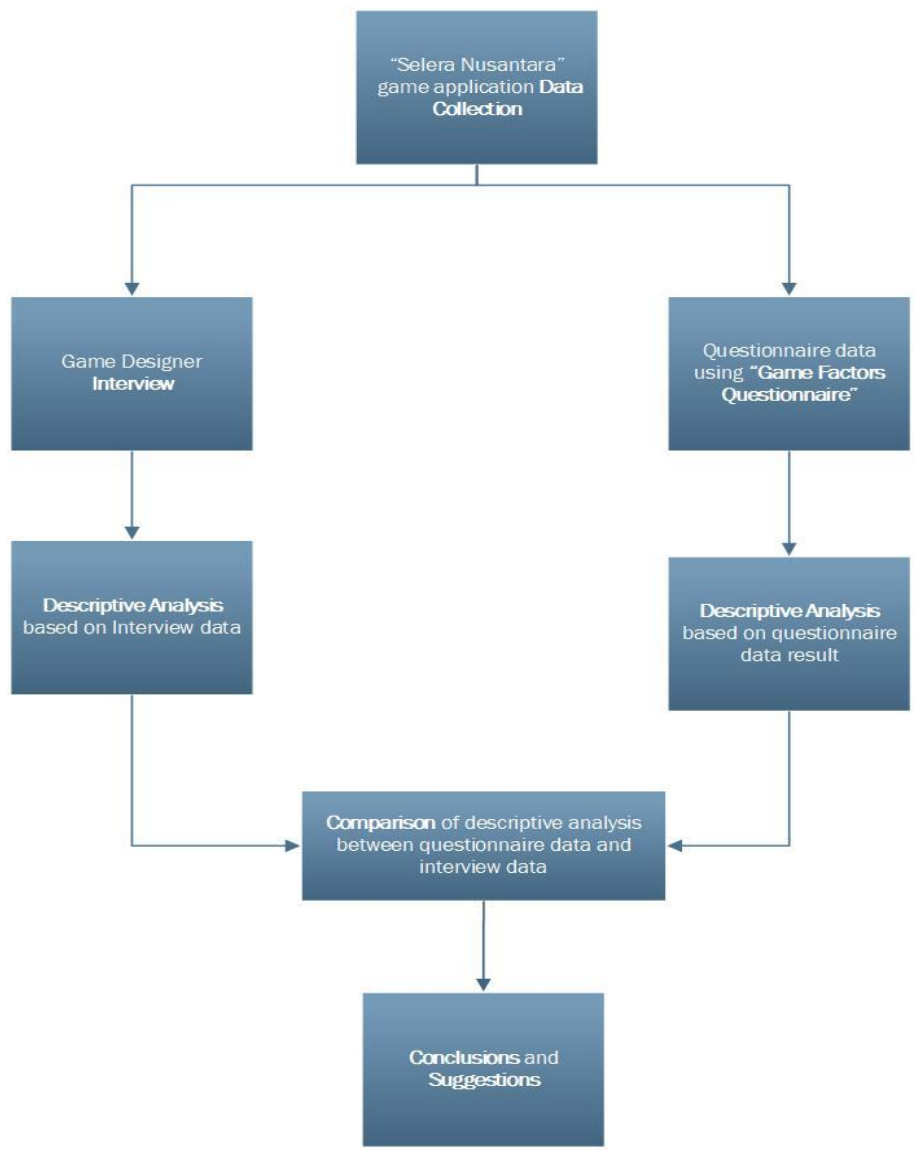

Figure 1. Research Method

Widhiyanti, Dewangga, Almukthar (Game Design Factor Questioner in User Experience Analysis on Selera Nusantara Game) 


\subsection{Interview with Game Designer}

In this study, interviews were conducted with Game Designer from Selera Nusantara Game, Gambir Studio. Questions were compiled and asked for Game Designers using the basic criteria from the Game Design Factor Questionnaire (GDFQ) using 11 criteria out of 12 criteria. Game Goals, Game Mechanism, Interaction, Freedom, Fantasy Game, Narrative, Sensation, Game Value, Challenge, Mystery, Flow are the 11 criteria used in compiling questions for interviews. The interview results will be used as comparison data from the results of questionnaire analysis for users of Selera Nusantara Game. This comparison analysis will be used to see the suitability between the design of the development team and the results of User Experience Evaluation using the Game Design Factor Questionnaire instrument in this study.

\subsection{Research Instruments}

Testing using a questionnaire conducted through offline and online media. Online data collection using Google Form media. The instrument used in this study is an instrument from the Game Design Factor Questionnaire that is modified and adapted to the characteristics of the game testing. The basis of The Game Design Factor Questionnaire consists of 12 factors namely Game Goals, Game Mechanism, Interaction, Freedom, Fantasy Game, Narrative, Sensation, Game Value, Social, Challenge, Mystery, and Flow. There is one factor that is Social that is not used in this study, because Selera Nusantara Game has a game character that does not require friends or groups to play it. A questionnaire made of 11 factors and produces 37 questions that will be given to respondents. The Game Design Factor Questionnaire was designed with Likert Scale using 5 Scale Measurement. Table 1 shows 37 questions that will be asked questionnaires tailored to the Selera Nusantara Game.

Table 1. Game Design Factor Questionnaire for Game Selera Nusantara

\begin{tabular}{|c|c|c|}
\hline No & Game Factor & Question \\
\hline \multirow[t]{3}{*}{1} & \multirow[t]{3}{*}{ Game Goals } & "Selera Nusantara Game" has clear tasks and stages \\
\hline & & I know what my purpose is when playing "Selera Nusantara Game" \\
\hline & & $\begin{array}{l}\text { I want to complete the goal and get the best results when playing "Selera } \\
\text { Nusantara Game" }\end{array}$ \\
\hline \multirow[t]{3}{*}{2} & \multirow[t]{3}{*}{$\begin{array}{l}\text { Game } \\
\text { Mechanism }\end{array}$} & $\begin{array}{l}\text { The flow of the game (gameplay) and the genre of Selera Nusantara is } \\
\text { clear }\end{array}$ \\
\hline & & The rules in the game Selera Nusantara are clear \\
\hline & & I like the flow of the game (gameplay) Selera Nusantara \\
\hline \multirow[t]{3}{*}{3} & \multirow[t]{3}{*}{ Interaction } & How to play "Selera Nusantara Game" is easy to do and understand \\
\hline & & The Help feature and advice in play given is clear and tells me what to do \\
\hline & & $\begin{array}{l}\text { Interaction with devices / tools / equipment in "Selera Nusantara Game" } \\
\text { feels fun }\end{array}$ \\
\hline \multirow[t]{3}{*}{4} & \multirow[t]{3}{*}{ Freedom } & I can organize my own data in "Selera Nusantara Game" \\
\hline & & I can play "Selera Nusantara Game" in various ways to play \\
\hline & & I can make my own playing record in "Selera Nusantara Game". \\
\hline \multirow[t]{3}{*}{5} & \multirow[t]{3}{*}{ Game Fantasy } & The art style blends with the game theme and is consistent \\
\hline & & $\begin{array}{l}\text { Scenes and characters correspond to the atmosphere of the original } \\
\text { environment. }\end{array}$ \\
\hline & & The story is told according to the mechanics of the game. \\
\hline \multirow[t]{3}{*}{6} & \multirow[t]{3}{*}{ Narrative } & "Selera Nusantara Game" has a clear storyline \\
\hline & & "Selera Nusantara Game" has a plausible storyline \\
\hline & & e want to know the continuation of the \\
\hline
\end{tabular}

Widhiyanti, Dewangga, Almukthar (Game Design Factor Questioner in User Experience Analysis on Selera Nusantara Game) 


\begin{tabular}{|c|c|c|}
\hline No & Game Factor & Question \\
\hline & & "Selera Nusantara Game" \\
\hline \multirow[t]{5}{*}{7} & \multirow[t]{5}{*}{ Sensation } & $\begin{array}{l}\text { Coloring and laying objects (layout) on the display "Selera Nusantara } \\
\text { Game" caught my attention }\end{array}$ \\
\hline & & $\begin{array}{l}\text { The icons and functions of the buttons in "Selera Nusantara Game" are } \\
\text { clear and work well }\end{array}$ \\
\hline & & Nusantara taste is very rich in audio and graphics \\
\hline & & $\begin{array}{l}\text { Naming the characters in "Selera Nusantara Game", reminds me of } \\
\text { figures in the Indonesian culinary world }\end{array}$ \\
\hline & & $\begin{array}{l}\text { "Selera Nusantara Game" membuat saya mengetahui dan "merasakan" } \\
\text { kuliner Nusantara }\end{array}$ \\
\hline \multirow[t]{4}{*}{8} & \multirow[t]{4}{*}{ Game Value } & I want to get as many scores/items as I can. \\
\hline & & $\begin{array}{l}\text { The content in "Selera Nusantara Game" is quite a lot and interesting to } \\
\text { play. }\end{array}$ \\
\hline & & I found a cultural element in "Taste of Nusantara Game" \\
\hline & & $\begin{array}{l}\text { My knowledge of Nusantara culinary becomes increased after playing } \\
\text { "Selera Nusantara Game" }\end{array}$ \\
\hline \multirow[t]{3}{*}{9} & \multirow[t]{3}{*}{ Challenge } & "Selera Nusantara Game" has a Challenge that I want to solve \\
\hline & & I can complete tasks on "Selera Nusantara Game" easily \\
\hline & & I'm looking forward and want to play the next chapter. \\
\hline \multirow[t]{2}{*}{10} & \multirow[t]{2}{*}{ Mystery } & "Taste of Nusantara Game" has many surprises \\
\hline & & $\begin{array}{l}\text { Before I finish the game, I want to know more about the contents of } \\
\text { "Selera Nusantara Game" }\end{array}$ \\
\hline \multirow[t]{4}{*}{11} & \multirow[t]{4}{*}{ Flow } & I am very focused when playing Selera Nusantara \\
\hline & & I don't feel tired when playing "Selera Nusantara Game" \\
\hline & & I sometimes forget the time when playing "Selera Nusantara Game" \\
\hline & & $\begin{array}{l}\text { I pay less attention to the surrounding environment, at the time of playing } \\
\text { "Selera Nusantara Game" }\end{array}$ \\
\hline
\end{tabular}

\subsection{Survey}

The survey was conducted online by sharing google form links and disseminated through WhatsApp application to respondents [10]. Respondents will fill out a Google form and the collected results will be analyzed by researchers, Survey questions using the Game Design Factor Questionnaire instrument with Linkert Scale using 5 Scale Measurement Form.

\subsection{Participant}

Respondents in this study had age criteria of 17-35 years with a background as diverse as students, students, and employees. The criteria of these respondents are based on the target game players Selera Nusantara Game who have a fairly broad age range and specifically for respondents from Indonesia.

\subsection{Data Analysis}

The analytical methods used in this study are Qualitative Description for interview results and quantitative descriptive for survey results. Qualitative description is qualitative research that tries to understand, explore and penetrate a very deep symptom, then interpret and conclude these symptoms according to the context. Quantitative research attempts to solve problems (find answers) through rigorous design (e.g. correlation, experimentation, and quantitative descriptive) to reach objective conclusions. In the process of quantitative analysis is done data processing and conducting validation

Widhiyanti, Dewangga, Almukthar (Game Design Factor Questioner in User Experience Analysis on Selera Nusantara Game) 
tests using methods. A validity test is an accuracy between the collected data and the actual data that occurs on the object studied [11].

A reliability test on a research instrument is a test used to find out whether a questionnaire used in the collection of research data can already be said to be reliable or not. The study conducted reliability tests using the Cronbach's Alpha method. A questionnaire is said to be reliable or reliable if a person's answer to a statement is consistent or stable over time [13]. This method will calculate the alpha value, if the alpha value is close to 1 then the internal consistency reliability is higher. In the next step, the results of data collection obtained from the questionnaire will be calculated as a percentage for each criterion of the Game Design Factor Questionnaire (GDFQ). The results of the survey data calculation will be visualized using the Pie Chart. The results of the questionnaire will be described quantitatively and will be compared with interview data with game designers to see the results.

\section{Result and Discussion}

\subsection{Description Based on Interview with Game Designer}

The interview was conducted to get information related to the design process of the Selera Nusantara Game. The interviewees were game designers, game artists, and game programmers from Gambir Studio for Selera Nusantara Game. The results of the interview obtained, namely the Selera Nusantara Game, include casual games that will be played casually without players becoming very attached to the game. The initial idea of designing the Selera Nusantara Game is from the business side, that games that have many fans one of which is a game with a casual genre and has a gameplay that is easy to play. Some similar games that also have a lot of fans such as Pizza Frenzy et al. Games with this criteria, will continue to have players for a considerable period. The next idea in terms of content selection from the game is Nusantara cuisine, this is because no game raises the theme of Nusantara food that becomes the daily food of the community optimally both in terms of game design and longterm player maintenance. In addition, indirectly, the idea of lifting Nusantara food can provide experience to users to the memories of Indonesian food menus that are commonly consumed by the community, including with the design of the environment, character, and storytelling.

This game is designed for players in the age range of 15-35 years who already have a lot of experience with the situation of buying and selling typical Nusantara food, but in its marketing, the Selera Nusantara Game can be played in a very wide age range. The target players of the Selera Nusantara Game are Indonesians of the female gender who have the characteristics of generally Indonesian women and non-gamer. Selera Nusantara Game is designed with gameplay that is very easy to play and has a story that Indonesia once in accordance with the target players who are women and not gamers. Selera Nusantara Game is expected to provide entertainment in the form of games that are easy to play with game objects that are familiar to the players. Gambir studio also has several game products that raise the theme of food but with gender targets that are still general and of course have gameplay and feature designs that are different from Selera Nusantara Game. Analysis of the results of the interview can be seen in Table 2 .

Table 2. Interview Results Game Design Factor Questionnaire of Selera Nusantara Game

\begin{tabular}{lll}
\hline No & Game Factor & \multicolumn{1}{c}{ Hasil Interview } \\
\hline 1 & Game Goals & $\begin{array}{l}\text { The game is designed with easy gameplay and features that are easy for players } \\
\text { to understand. The hope is that once players enter the game, they can } \\
\text { immediately understand how the game will be played and be completed easily. }\end{array}$ \\
\hline 2 & $\begin{array}{l}\text { Game } \\
\text { Mechanism }\end{array}$ & $\begin{array}{l}\text { The game flow is made simple by starting with a tutorial and every new } \\
\text { character or asset will be given another tutorial, so players can play it right }\end{array}$ \\
\hline
\end{tabular}

\footnotetext{
Widhiyanti, Dewangga, Almukthar (Game Design Factor Questioner in User Experience Analysis on Selera Nusantara Game)
} 


\begin{tabular}{|c|c|c|}
\hline & & away. \\
\hline 3 & Interaction & $\begin{array}{l}\text { Features are made simple and very easy to understand by users. The hope of } \\
\text { designing simple features and interactions can make players able to directly play } \\
\text { the Selera Nusantara Game without having to think extra to understand the } \\
\text { features and interactions that exist. }\end{array}$ \\
\hline 4 & Freedom & $\begin{array}{l}\text { There is no feature that gives players the freedom to manage their own account } \\
\text { and game targets, maybe in the future, this feature can also be designed for the } \\
\text { development of the Selera Nusantara Game. }\end{array}$ \\
\hline 5 & Game Fantasy & $\begin{array}{l}\text { The artistic design is not too difficult for users to understand because the } \\
\text { visualized food is authentic Indonesian food and is usually consumed by the } \\
\text { general public. So when players see food and environmental assets, players can } \\
\text { immediately understand and feel that they are in the environment and eating } \\
\text { food that is usually consumed. The design doesn't provide much additional } \\
\text { information with the text because the design is very similar to the original } \\
\text { condition. }\end{array}$ \\
\hline 6 & Narrative & $\begin{array}{l}\text { The story presented in the Selera Nusantara Game is not the focus of this game, } \\
\text { the story is only a "sweetener" in this game. The story is made simple with a } \\
\text { soap opera-like concept because it is adapted to the target market, which on } \\
\text { average are soap opera fans. }\end{array}$ \\
\hline 7 & Sensation & $\begin{array}{l}\text { The interface design was developed using references to food-themed games that } \\
\text { have succeeded in marketing their games. For character selection, it can be seen } \\
\text { from the names used, namely using names that are familiar in Indonesia. } \\
\text { Inspired by the names of famous chefs in Indonesia, but in terms of character } \\
\text { design, it does not point to these figures. } \\
\text { In terms of objects, namely food, and beverages, it focuses on foods that are } \\
\text { commonly consumed in Indonesia with the hope that users will immediately } \\
\text { recognize them and no special educational method is needed to introduce food. }\end{array}$ \\
\hline 8 & Game Value & $\begin{array}{l}\text { The target player is only limited to finishing playing for each chapter and will } \\
\text { get coins that can be used in the next game }\end{array}$ \\
\hline 9 & Challenge & $\begin{array}{l}\text { Players will be Challenged to complete the game and unlock the next chapter. } \\
\text { Each month will be given a new menu which is a new Challenge that players } \\
\text { have been waiting for. }\end{array}$ \\
\hline 10 & Mystery & $\begin{array}{l}\text { The player's curiosity is processed from the side of the story which has a plot } \\
\text { like a soap opera and there are new chapters that will be opened for a month } \\
\text { with menus that are not yet known by players. }\end{array}$ \\
\hline & Flow & $\begin{array}{l}\text { The target of these players is casual gamers whose characters can't linger to } \\
\text { access their devices. So this Indonesian-style game will not cause players to } \\
\text { become too focused on the game. The game is played in a relaxed manner and } \\
\text { each level can be completed within } 1-2 \text { minutes. }\end{array}$ \\
\hline
\end{tabular}

\subsection{Characteristics of Respondents}

The target respondents in this survey stage are respondents who have criteria, namely Indonesians who have played the Selera Nusantara Game for at least 2 chapters, the age range of 18-35 years, and are willing to fill out the questionnaire given. The number of respondents obtained in this study as many as 18 respondents with a distribution of criteria that are $65 \%$ male and $35 \%$ female, this is actually not in accordance with the target of game designer design regarding the gender target of female players who are not gamers. The age of respondents obtained varies, namely $66.6 \%$ aged $18-25$ years, ages 26-35 years as much as $22 \%$, and ages 8-14 years as much as $11.3 \%$. In terms of employment obtained information, $85 \%$ of respondents are students or students and the next $15 \%$ are employees.

Widhiyanti, Dewangga, Almukthar (Game Design Factor Questioner in User Experience Analysis on Selera Nusantara Game) 


\subsection{Validity Test and Reliability Test of Questionnaire Results}

Before conducting quantitative descriptive analysis on the results of the questionnaire obtained, the data that had been collected was first carried out with a Validity Test and Reliability Test. Validity test of the research instrument is considered valid if each question item in the questionnaire can be used to reveal something that will be measured by the questionnaire [12]. The method used in the validity test is the Product Moment Correlation Test and obtained results as in Table 4. The Validity Test was conducted on 37 alignments submitted on the questionnaire. The results of validity are known that the question in criterion 9 is the "Challenge" regarding the Challenge of completing the Selera Nusantara Game is an invalid statement, so it does not participate in the reliability test and quantitative description analysis stage. Statements that are "invalid" have a value of rHitung < rTable.

The accuracy of a questionnaire is obtained if someone's answer statement is consistent or stable over time [14]. The next step is a reliability test using the Cronbach's Alfa method against 36 valid statements calculated in each criteria group. The reliability criteria are based on Gilford's Reliability Comparison, in Table 4. The results of the reliability test can be seen in Table 5 and obtained results of "high reliability" and "very high reliability", so that the results of the questionnaire can be used.

Table 3. Gilford Reliability Coefficient

\begin{tabular}{ll}
\hline \multicolumn{1}{c}{ Reliability Coefficient } & \multicolumn{1}{c}{ Reliability Criteria } \\
\hline $0,80 \leq \mathrm{r}_{11} \leq 1.00$ & Very High \\
\hline $0,60 \leq \mathrm{r}_{11}<0,80$ & High \\
\hline $0,40 \leq \mathrm{r}_{11}<0,60$ & Average \\
\hline $0,20 \leq \mathrm{r}_{11}<0,40$ & Low \\
\hline $0,00 \leq \mathrm{r}_{11}<0,20$ & Veru Low (unreliable) \\
\hline
\end{tabular}

Table 4. Cronbach's Alpha Reliability Test

\begin{tabular}{llcl}
\hline No & Game Factor & $\begin{array}{c}\text { Reliability } \\
\text { Coefficient }\end{array}$ & $\begin{array}{c}\text { Reliability } \\
\text { Criteria }\end{array}$ \\
\hline 1 & Game Goals & 0,81 & Very High \\
\hline 2 & Game Mechanism & 0,90 & Very High \\
\hline 3 & Interaction & 0,88 & Very High \\
\hline 4 & Freedom & 0,93 & Very High \\
\hline 5 & Game Fantasy & 0,87 & Very High \\
\hline 6 & Narrative & 0,87 & Very High \\
\hline 7 & Sensation & 0,95 & Very High \\
\hline 8 & Game Value & 0,92 & Very High \\
\hline 9 & Challenge & 0,94 & Very High \\
\hline 10 & Mystery & 0,78 & High \\
\hline 11 & Flow & 0,90 & Very High \\
\hline & & & \\
\hline
\end{tabular}

Widhiyanti, Dewangga, Almukthar (Game Design Factor Questioner in User Experience Analysis on Selera Nusantara Game) 
4.4. Quantitative Description Analysis Based on Game Design Factor Questionnaire (GDFQ) and Interview Results

The results obtained from the Game Design Factor Questionnaire (GDFQ) which are directly compared to the results of interviews with game developers are as follows:

\subsubsection{Game Goals}

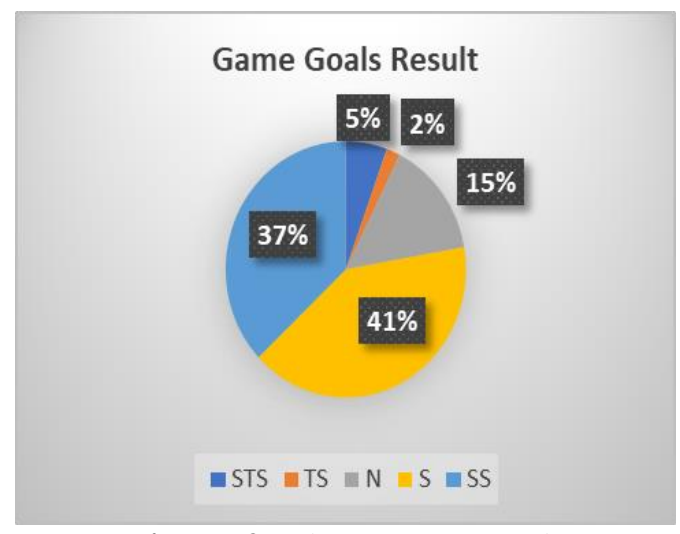

Figure 2. Chart Game Goals

Game goals are the ultimate goal of this game, usually in the form of rewards for the completion of a game. The results of the questionnaire obtained that as many as $37 \%$ chose to strongly agree and $41 \%$ agreed that Selera Nusantara Game has and provides a clear goal regarding the reward that players will receive when completing each level of the game. Percentages agree and strongly agree to give high numbers and these results are in accordance with the design of the game designer that provides a clear end goal for its users.

\subsubsection{Game Mechanism}

The Game Mechanism Factor discusses the way or flow when playing a game. A flow that is easy and clear to play will provide satisfaction for the user and make users do not have to think too much when playing it. The results of the questionnaire on this game mechanism were obtained 39\% of respondents had "strongly agreed" and $46 \%$ of respondents chose "agree", summed then for this factor obtained a high figure of $85 \%$. This result is in accordance with the design of the game designer when making gameplay from Selera Nusantara Game that is to be easily played by its users and provide a good user experience.

Widhiyanti, Dewangga, Almukthar (Game Design Factor Questioner in User Experience Analysis on Selera Nusantara Game) 


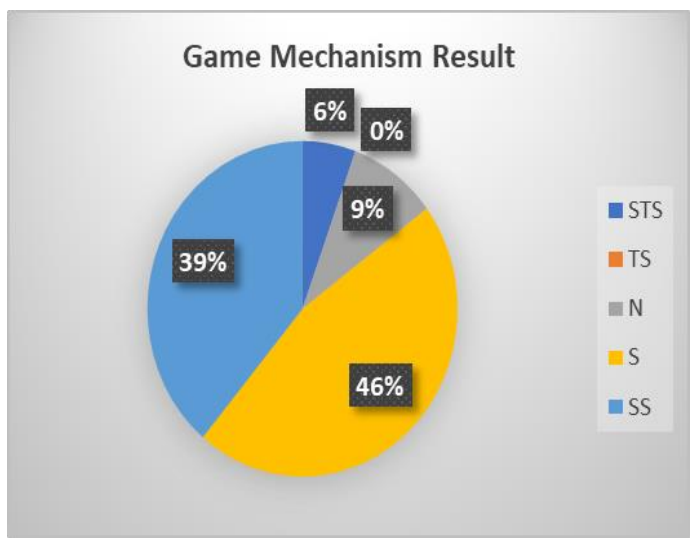

Figure 3. Chart Game Mechanism

\subsubsection{Interaction}

The Interaction Factor provides questionnaire results that most respondents choose "Strongly Agree" and "Agree" i.e. by $39 \%$ and $46 \%$, and if total to $85 \%$. When compared to neutral, disapproving, and strongly disagreeable results that are 9\%,0\%, and 6\%, it can be known if respondents are satisfied with the design of interaction between players and Selera Nusantara Game. This good interaction design will provide a good experience for the player. Game Designer Selera Nusantara Game managed to create a design that provides a good experience for Selera Nusantara Game players.

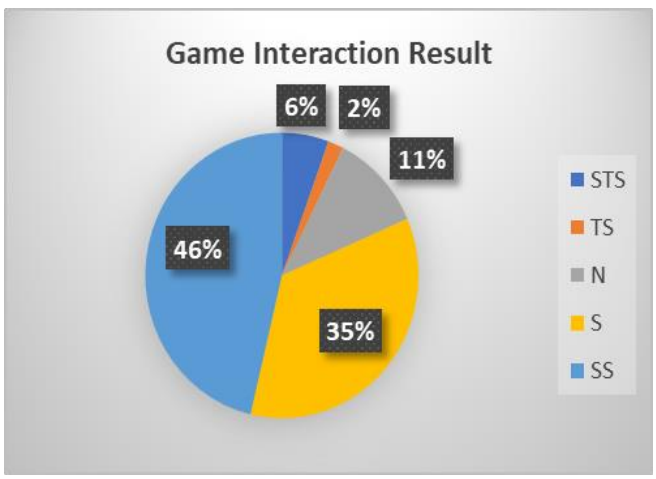

Figure 4. Chart Game Interaction 


\subsubsection{Freedom}

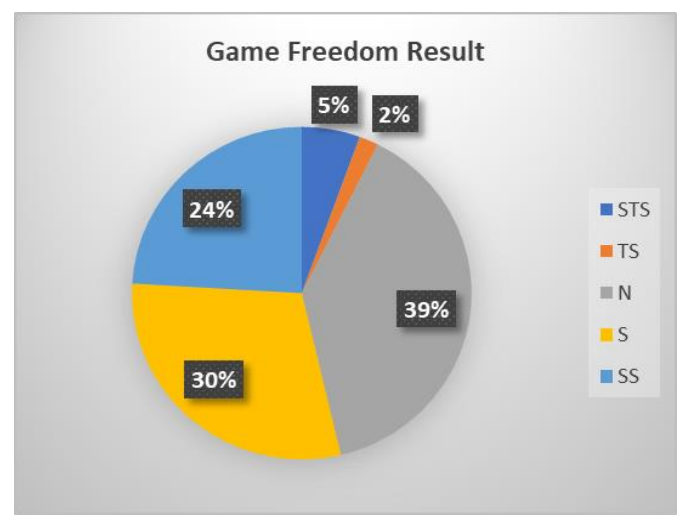

Figure 5. Chart Game Freedom

On the Freedom factor, respondents chose "Neutral" over "Strongly Agree", "Agree", "Disagree" and "Strongly disagree". The values obtained are "Strongly Agree" gets 24\%, the answer "Agree" 30\%, "Neutral" 39\%, the answer "Disagree" 2\% and the answer "Strongly disagree" only 5\%. The high value of "Neutral" here indicates that respondents have not understood the freedom of players in determining their own steps, targets, avatars, and other components in the Selera Nusantara Game. Based on the results of the interview it is known that Game Designer has not designed the freedom of control of the game to the user. However, this freedom factor provides input in the process of developing Selera Nusantara games in the future.

\subsubsection{Game Fantasy}

Fantasy games are factors that provide a place for players to imagine or fantasize about the game played. In the fantasy game factor, it is expected that players can enter into the story and visual design designed by the game designer. The results of the questionnaire obtained that as many as 30\% voted strongly in agreement and $48 \%$ agreed that Selera Nusantara Game has visualizations and stories that make players have experienced in situations and environments as designed by Game Designers.

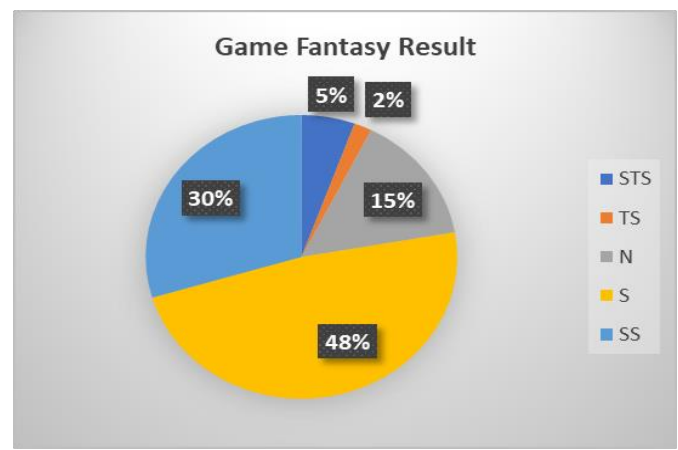

\subsubsection{Narrative}

Figure 6. Chart Game Fantasy

The narrative factor is a factor that processes from the side of the story. The results showed that respondents voted 28\% "Strongly Agree" and 39\% "Agreed". This high number compared to the choices of "Neutral", "Disapproving" and "Strongly Disagree" proves that the story given to Selera Nusantara Game provides such an experience in everyday life. The story design on Selera Nusantara Game was successful in providing an experience to users, in accordance with the expectations of the

Widhiyanti, Dewangga, Almukthar (Game Design Factor Questioner in User Experience Analysis on Selera Nusantara Game) 
Game Designer who designed stories such as soap operas that are very close to the daily life of the target players, namely Indonesian women.

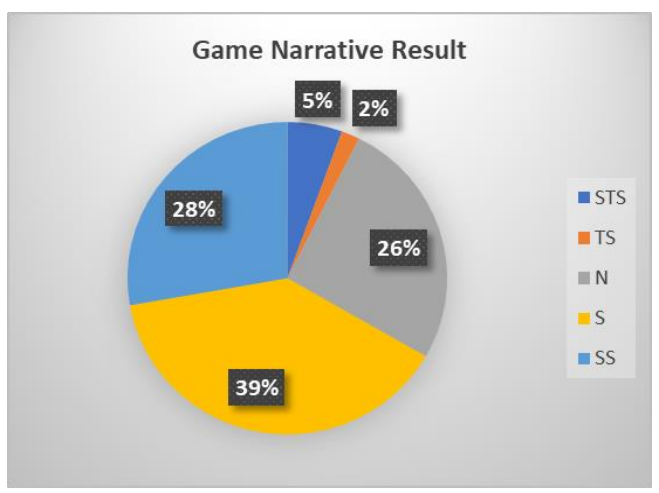

Figure 7. Chart Game Narrative

\subsubsection{Sensation}

On the Narrative factor, many respondents chose "Strongly Agree" which is 30\%, and "Agree" as much as $46 \%$. The result is very far compared to "Disagree" which is $3 \%$ and "Strongly Disagree" at $5 \%$. The results are very in accordance with the design of the game designer to provide experience for players and make players more interested in playing the game. Game Designer uses reference games similar that have a high sales rate, so players become very familiar with this type of game.

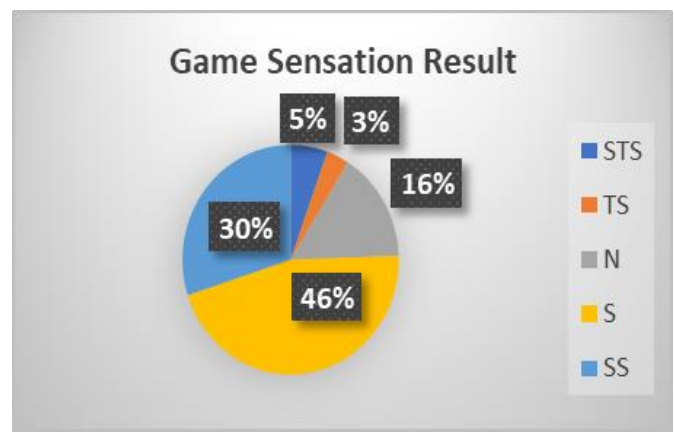

\subsubsection{Game Value}

Figure 8. Chart Game Sensation

The results of the game value analysis obtained the highest values in the answer "Agree" by $47 \%$ and "Strongly agree" by $32 \%$. This value shows that Selera Nusantara Same provides excellent value for its players. Game Designer provides an artistic-backed Nusantara cuisine theme that is very similar to the original. This provides the player with an experience of knowledge and memory of the cuisine that arises in the game. The value of the theme of cuisine and art design that is close to the original becomes an attraction for many people, especially Indonesians to play the Selera Nusantara Game.

Widhiyanti, Dewangga, Almukthar (Game Design Factor Questioner in User Experience Analysis on Selera Nusantara Game) 


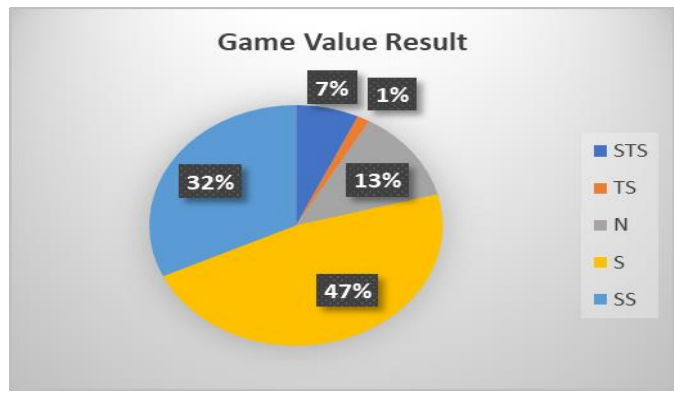

Figure 9. Chart Game Value

\subsubsection{Challenge}

Challenge is one of the factors that make people want to play a game. Selera Nusantara Game has a Challenge that is not too heavy because it is designed to be played in a relaxed situation and does not require a lot of time, but still provides an attraction for its players. The Challenge here is a positive Challenge that provides happiness for its users [15]. Game Designer provides simple Challenges such as adding buyers with more orders at each level increase, but with a limited time. In each chapter, there is a new cuisine served on the Selera Nusantara Game. It is also a Challenge for players to immediately complete tasks in each chapter. Game designers succeed in designing simple Challenges but still encourage players to play. This can be proven by the results of a questionnaire that shows an "Agree" value of $69 \%$.

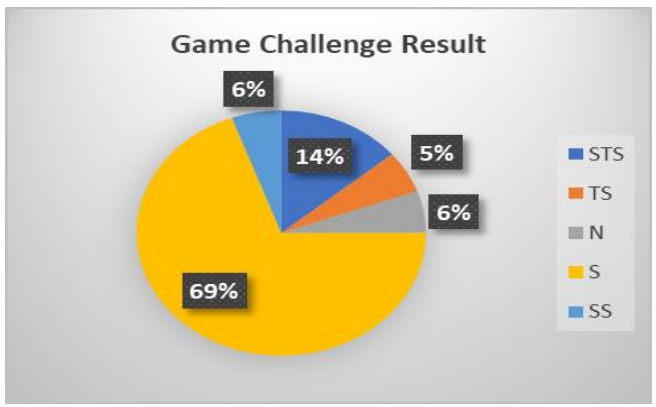

Figure 10. Chart Game Challenge

\subsubsection{Game Mystery}

Factor Game Mystery showed results of "Agree" by $39 \%$ and "Strongly Agree" by $22 \%$. Players agree that Game Selera Nusantara has surprises in each chapter, especially for the cuisines served. Game Designer designs for each month the tone of new cuisines issued, to keep players from having a different experience in each chapter. Players will wait for something new in the game Selera Nusantara.

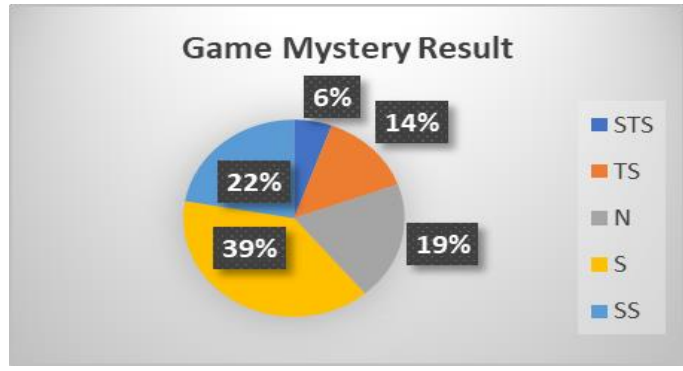

Figure 11. Chart Game Mystery

Widhiyanti, Dewangga, Almukthar (Game Design Factor Questioner in User Experience Analysis on Selera Nusantara Game) 


\subsubsection{Flow}

Unlike in the other 10 factors, the game flow factor provides almost balanced results between answers are "Strongly agree", "Agree", "Neutral", "Disagree", and "Strongly disagree". The percentages obtained are "Strongly Agree" at 20\%, "Agree" 29\%, "Neutral" 26\%, "Disagree" by 21\%, and "Strongly disagree" by $4 \%$. This shows that there are players who experience very focus in playing the Selera Nusantara Game so that they can ignore the surrounding environment. However, when compared to the design of the game designer, actually Selera Nusantara Game is designed to make the player not too focused on playing this game. The fast game completion time plan with gameplay that is not too difficult, will allow players to immediately complete the game and immediately return to the surrounding environment. This can happen if we look from the artistic side, the story, and mystery given to the Selera Nusantara Game, which makes some people focused on this game.

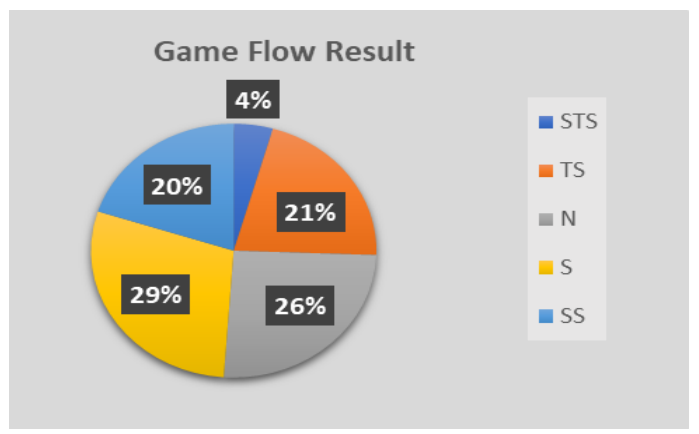

Figure 12. Chart Game Flow

\section{Conclusion}

The results of the evaluation that looked at the user experience using the Game Design Factor Questionnaire (GDFQ) against casual genre Selera Nusantara Game showed that the game designer had designed the Selera Nusantara Game concerning the characteristics and experience of the target player. This is indicated by the choice of "agree" and "strongly agree" which is above $75 \%$ on factor game goals, game mechanism, game interaction, fantasy games, narrative games, game sensation, game value, and game Challenge. In factor game freedom, game mystery and game flow obtained values with a not-so-significant difference between each selection criteria on the questionnaire shared. This happens because the game designer has not designed for the needs of users against factor freedom. The mystery factor and game flow have actually been designed in accordance with the user's experience, but it turns out that from the respondent data has similar results so there needs to be a review of this factor in order to get the expected goal.

\section{Acknowledgement}

I wish to express my deep thanks to Gambir Studio for their cooperation and the opportunity given to be able to evaluate the Game "Selera Nusantara" made by Gambir Studio. I also thank Dr. Firas Almukhtar from the Department of IT, Catholic University in Erbil, Kurdistan Region, Iraq for his support and assistance.

\section{References}

[1] Y. L. Prasetio, R. Wijaya, M. P. Sjah, M. R. Christian, and A. Chowanda, "Location-based game to enhance player's experience in survival horror game," Procedia Comput. Sci., vol. 116, pp. 206-213, 2017, doi: 10.1016/j.procs.2017.10.037.

[2] Y. R. Shi and J. L. Shih, "Game Factors and Game-Based Learning Design Model," Int. J.

Widhiyanti, Dewangga, Almukthar (Game Design Factor Questioner in User Experience Analysis on Selera Nusantara Game) 
Comput. Games Technol., vol. 2015, 2015, doi: 10.1155/2015/549684.

[3] R. Akhsani, A. K. Nalendra, M. Mujiono, and I. Ismanto, "Pengukuran User Experience Pada Aplikasi Pasbhara Dengan Metode Heuristic Evaluation," Res. J. Comput. Inf. Syst. Technol. Manag., vol. 3, no. 1, p. 38, 2020, doi: 10.25273/research.v3i1.6247.

[4] D. Apken, H. Landwehr, M. Herrlich, M. Krause, D. Paul, and R. Malaka, "Design and evaluation of parametrizable multi-genre game mechanics," Lect. Notes Comput. Sci. (including Subser. Lect. Notes Artif. Intell. Lect. Notes Bioinformatics), vol. 7522 LNCS, no. September, pp. 45-52, 2012, doi: 10.1007/978-3-642-33542-6_4.

[5] R. Irwandana, A. D. Herlambang, M. C. Saputra, D. A. Fatah, A. P. Novitasari, and H. Tolle, "Evaluasi dan Perancangan User Interface untuk Meningkatkan User Experience Menggunakan Metode Human-Centered Design dan Heuristic Evaluation Pada Aplikasi Ezypos," Rekayasa, vol. 2, no. 2, pp. 130-143, 2018.

[6] N. Rizky Akbar, E. Muhammad, A. Jonemaro, and T. Afirianto, "Evaluasi User Experience Pada Game Hearthstone Dengan Menggunakan Metode Game Experience Questionnaire," J. Pengemb. Teknol. Informasị dan Ilmu Komput., vol. 2, no. 12, pp. 7551-7558, 2018, [Online]. Available: http://j-ptiik.ub.ac.id.

[7] H. R. Ulinuha, E. Utami, and A. Sunyoto, "Evaluasi User Experience Pada Game Pes 2020 Menggunakan Metode Cognitive Walkthrough," Respati, vol. 15, no. 2, p. 45, 2020, doi: 10.35842/jtir.v15i2.347.

[8] R. I. Haikal, D. P. Agustino, I. M. Pasek, and P. Wijaya, "Evaluasi User Experience pada Game Genshin Impact menggunakan Metode Cognitive Walkthrough dan Persona," no. September 2020, pp. 17-25, 2021.

[9] T. A. M. Putra, S. H. Wijoyo, and R. I. Rokhmawati, "Evaluasi User Experience Pada Social Application Mobile HAGO Menggunakan Metode Enhanced Cognitive Walkthrough," Pengemb. Teknol. Inf. dan Ilmu Komput., vol. 3, no. 7, pp. 6721-6729, 2019, [Online]. Available: https://j-ptiik.ub.ac.id/index.php/j-ptiik/article/view/5795/2751 .

[10] A. Nurfitriya and T. C. Kusumandyoko, "Analisis User Experience Pada Game Among Us Dengan Menggunakan Game-Design Factors Questionnaire," Barik, vol. 2, no. 3, pp. 148-162, 2021, [Online]. Available: https://ejournal.unesa.ac.id/index.php/JDKV/article/view/42314.

[11] H. Halin, "Pengaruh Kualitas Produk Terhadap Kepuasan Pelanggan Semen Baturaja di Palembang pada PT Semen Baturaja (Persero) Tbk," J. EcoMent Glob., vol. 3, no. 2, pp. 167$182,2018$.

[12] S. K. Dewi and A. Sudaryanto, "Validitas dan Reliabilitas Kuisioner Pengetahuan, Sikap dan Perilaku Pencegahan Demam Berdarah," Semin. Nas. Keperawatan Univ. Muhammadiyah Surakarta 2020, pp. 73-79, 2020.

[13] I. D. Sabukunze and A. Arakaza, "User Experience Analysis on Mobile Application Design Using User Experience Questionnaire," Indones. J. Inf. Syst., vol. 4, no. 1, pp. 15-26, 2021, [Online]. Available: https://ojs.uajy.ac.id/index.php/IJIS/article/view/4646.

[14] I. Windy Helena, Sudarwati, "Analisis Kinerja Karyawan Bank Panin KCU Kota Surakarta," Edunomika, vol. 04, no. 02, pp. 357-368, 2020.

[15] R. T. Pantouw and D. T. H. Aruan, "Influence of Game Design and Playability Toward Continuance Intention Using TAM Framework," IPTEK J. Proc. Ser., vol. 0, no. 5, p. 307, 2019, doi: 10.12962/j23546026.y2019i5.6344. 